\title{
THE HARDWARE IMPLEMENTATION OF DEMONSTRATOR AIR INDEPENDENT ELECTRIC SUPPLY SYSTEM BASED ON PEM FUEL CELL
}

\author{
Grzeczka G., PhD \\ Szymak P., PhD \\ Institute of Electrical Engineering and Automatics \\ Polish Naval Academy, Poland
}

\begin{abstract}
The paper presents results of the research project whose the main goal was to build a technology demonstrator of an electric supply system based on the PEM fuel cell. The electric supply system is dedicated to operation on a board of a submarine during emergency situations. The underwater conditions influence on a specific architecture of supply subsystems of the PEM fuel cell system. In this case the fuel cell stack is supplied by both clean hydrogen and clean oxygen stored in pressurized tanks. The hydrogen has to be delivered in a closed loop, while the oxygen can be delivered in a closed or an open loop. In the technology demonstrator, the supply of the fuel cell stack by the hydrogen in the closed loop and the oxygen in the open loop with a precise control of its flow were used.

In the paper, a hardware and a software structures of the technology demonstrator are presented. Then, selected results of the PEM fuel cell system operation are included. The results of the research show precise control of the oxygen and a response of the system on rapid changes of an electric load responding to the loads working during an emergency situation on a board of a submarine. Mainly, results of the real fuel cell system operation are presented. The results of numerical research can be found in several publications of the authors included in the bibliography of the paper.
\end{abstract}

Keywords: PEM fuel cell system, Air Independent System, control of oxygen

\section{INTRODUCTION}

More often, hydrogen fuel cells are used to supply different devices and vehicles both for civilian and military applications. One of the more popular hydrogen fuel cells used in mobile applications are low-temperature PEM (Proton Exchange Membrane) fuel cells. This technology is also used with success in underwater mobile platforms. Nowadays, there are constructions of submarines and unmanned underwater vehicles using PEM stacks to generate an electric energy needed for their working. The most mature examples of underwater platform with PEM fuel cells are German submarine class 214 [4] and Japan AUV (Autonomous Underwater Vehicle) Urashima [16]. Another interesting examples of using fuel cell in marine application are AUV Hugin [5] with alkaline aluminium hydrogen peroxide semi fuel cell and AUV Clipper [6] using magnesium fuel and oxygen from the sea. The main reason for using the fuel cell technology in mobile applications, especially in underwater vehicles, is currently the highest achievable energy density. Having such an energy source can be especially useful in the emergency situation on board of a submarine. Surviving underwater on board of the submarine during its failure until the rescue units approach and help is only possible when the crew has access to power supply of life support systems and communications.

Mentioned above benefits justify using PEM fuel cells additionally to technologically advanced chemical batteries currently used on submarines or unmanned underwater vehicles [7]. The hybrid combination of these two energy sources should provide a masked operation with mentioned above possibility of surviving underwater in case of emergency situations.

The use of hydrogen to power mobile platforms is currently very carefully examined solution in terms of both the marine [17] and land or air. 
This paper presents selected results of carried out research whose the main objective was to build technology demonstrator to achieve knowledge and experience allowing to develop the essential requirements for this type of equipment in the submarine environment. In the next sections, following stages of the project are described.

The project was carried out in the following stages:

1) Measurement on board of a submarine,

2) Designing mathematical model of the fuel cell system,

3) Building the technology demonstrator of the fuel cell system,

4) Experimental research.

The project was finished by making recommendations for future research and/or purchase of this kind of power system on board of a submarine.

\section{MEASUREMENT ON BOARD OF SUBMARINE}

The demand for electrical energy, and thus the use of individual electrical consumers on board of a submarine is dictated by the exploitation state, which she is at the moment. Exploitation states of the ship depend only on the nature of the tasks performed by her. Despite diversity and variability of conditions in which these tasks are performed, there are four exploitation states, which can be considered in terms of the use of emergency supply: moving the ship to the area of operation, operating a ship in the area of operation, the ship lying at the bottom in the area of operation and the ship lying at the bottom - the failure of the submarine.

During the measurements on board of a submarine, identification of following processes was carried out: processes of generating, converting and transmission of electric energy on board of the selected submarine not only in a failure state, but also during all exploitation states of the ship. Below, there are presented results of measurements of low energy demand exploitation states, that are especially significant for discussed subject. The first state is lying on the seabed, Tab.1. The main electric motor is stopped but in a stand-by mode. The manoeuvring desktop is supplied. The commander may decide to turn off additional devices in case of the task or tactical situation that requires long lasting lying on the seabed and complete silence on the ship.

Tab. 1. Demand for energy in the state "lying on the seabed".

\begin{tabular}{|c|c|c|}
\hline Type of power supply & $\begin{array}{c}\text { Current } \\
\text { A }\end{array}$ & $\begin{array}{c}\text { Power } \\
\text { kW }\end{array}$ \\
\hline $156-220 \mathrm{DC}$ & 35,58 & 6,76 \\
\hline $115 \mathrm{~V} 60 \mathrm{~Hz}$ & 34,8 & 4,00 \\
\hline $110 \mathrm{~V} \mathrm{DC}$ & 0,25 & 0,03 \\
\hline $115 \mathrm{~V} 400 \mathrm{~Hz}$ & 29,98 & 3,45 \\
\hline $24 \mathrm{~V} \mathrm{DC}$ & 5,00 & 0,12 \\
\hline $220 \mathrm{~V} 60 \mathrm{~Hz}$ & 3,00 & 0,66 \\
\hline TOTAL & $\mathbf{1 0 8 , 6 1}$ & $\mathbf{1 5 , 0 1}$ \\
\hline
\end{tabular}

While lying on the seabed the energy demand is seven times lower than in a low speed movement. The use of the fuel cells in that state, allows to stay for a long period of time in the submerged state without necessity of energy replenishment.

The failure of a submarine, lying on the seabed is very important hypothetical state, in which the submarine can be after a failure, collision with a submerged object and falling to the bottom. From the survival point of view, and in consequence the crew rescue of the damaged submarine, providing sufficient amount of energy is essential for successful rescue action. Power consumption in this state is limited to the minimum, Tab. 2. But it is totally dependent on the right operation of the devices after the event which led the submarine to the state of lying on the seabed.

Tab. 2. Demand for energy in the state "failure of a submarine".

\begin{tabular}{|c|c|c|}
\hline Type of power supply & $\begin{array}{c}\text { Current } \\
\text { A }\end{array}$ & $\begin{array}{c}\text { Power } \\
\text { kW }\end{array}$ \\
\hline $156-220 \mathrm{DC}$ & 21,00 & 3,99 \\
\hline $115 \mathrm{~V} 60 \mathrm{~Hz}$ & 14,00 & 1,61 \\
\hline $110 \mathrm{~V} \mathrm{DC}$ & & \\
\hline $115 \mathrm{~V} 400 \mathrm{~Hz}$ & & \\
\hline $24 \mathrm{~V} \mathrm{DC}$ & 3,60 & 0,09 \\
\hline $220 \mathrm{~V} 60 \mathrm{~Hz}$ & & \\
\hline TOTAL & $\mathbf{3 8 , 6 0}$ & $\mathbf{5 , 6 9}$ \\
\hline
\end{tabular}

In the considered state, there are presented the power demand of the devices, which should be powered on, regarding their operational ability and energy supply.

Relating to the actual trends of rescue mission for the crew of the damaged submarine, the crew should survive on the submarine even two weeks. That is possible by having adequate amounts of means of sustaining life on the submarine and emergency electric energy sources.

It was found that the levels of demand for electric energy for both failure state and the ship lying at the bottom in the area of operation are of the same order.

The results of this research helped to determine the power requirements for designed system and indicated the possibilities of using emergency power supply based on PEM fuel cells for operation in two mentioned above exploitation states of the submarine.

\section{MATHEMATICAL MODEL OF FUEL CELL SYSTEM}

In parallel with the measurement described in the previous section, a mathematical model of the emergency power system based on PEM fuel cells C was designed. In the Fig. 1, block diagram of the emergency power systems based on PEM fuel cells is presented. While in the Fig. 2, schematic diagram of the system is shown. 


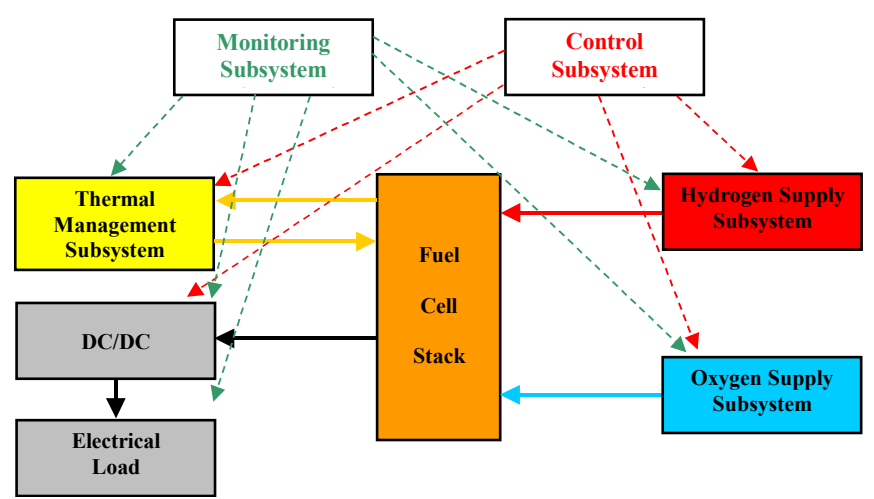

Fig. 1. Block diagram of emergency power supply system based on hydrogen fuel cell

The main result of this stage is the mathematical description of the fuel cell system operation in the form of differential equations and matrix equations of state implemented in Simulink environment (Fig. 2). All the subsystems (Fig. 1) are illustrated by different colors. Elements of the control subsystem are integrated with other subsystems, especially blocks named 'PID'.
In the designed power supply system (Fig. 2) the mathematical model of fuel cell stack with following features was used:

1) an analytical,

2) control-oriented,

3) steady-state,

4) isothermal,

5) cell-averaged.

The model of the fuel cell stack includes:

1) model of overall fuel cell stack voltage,

2) cathode and anode flow models,

3) membrane hydration model.

The mathematical description of the model used in the research is described in more details in [2][3][13]. The model of the fuel cell stack is mainly destined for control purposes. There are also alternative models of fuel cell stacks included in literature which are focused on other features and destined for other purposes, e.g. 3D model of gasses flows [10], model of polymeric super ionic membranes for fuel cell [1], another approach to control of the fuel cell systems [11], etc.

For graphical user interface with fuel cell model (Fig. 2) Matlab window, illustrated in the Fig. 3, was designed.

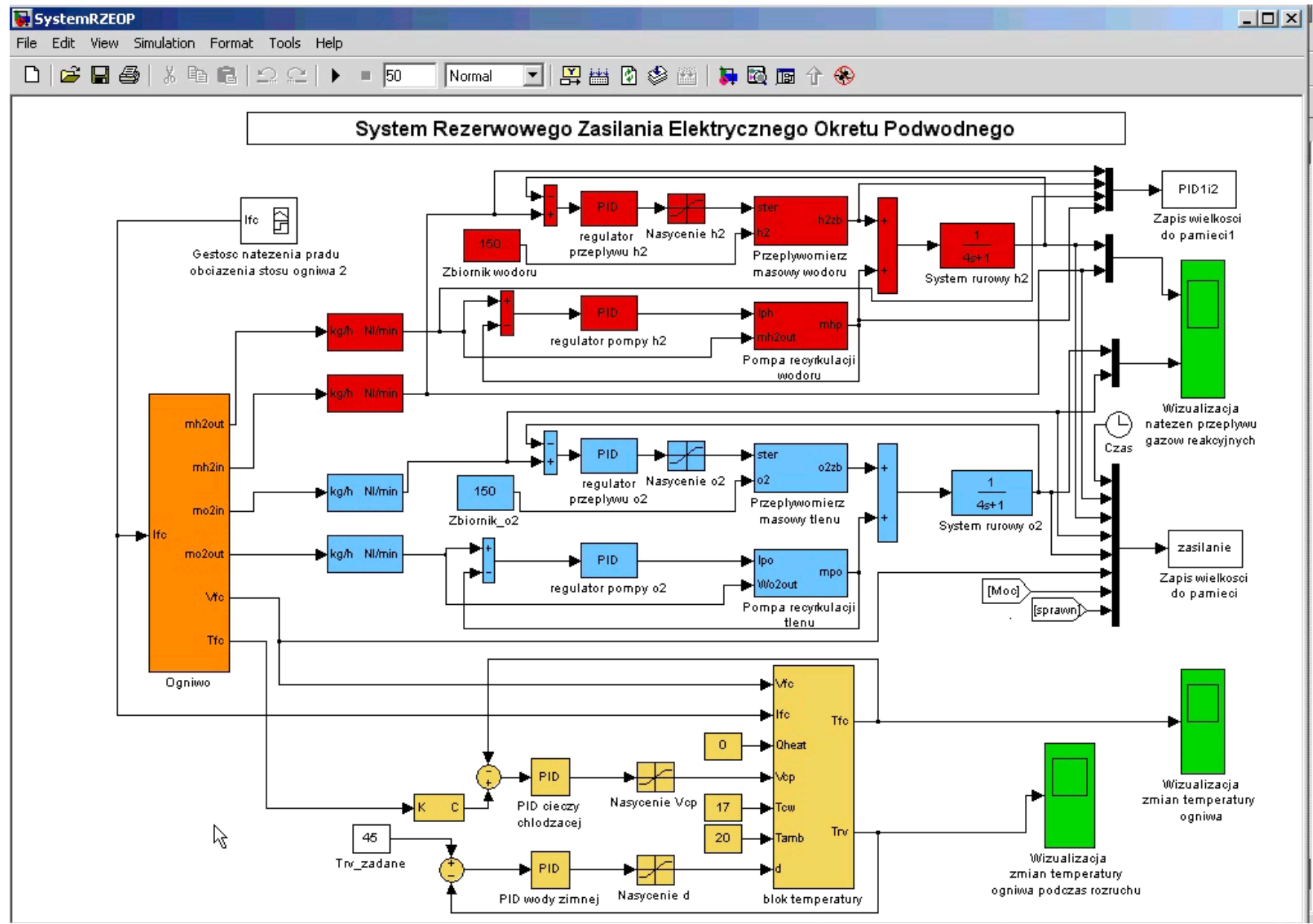

Fig. 2 Implementation of the PEM fuel cells model in Simulink environment (orange blocks: fuel cell stack, red blocks: hydrogen supply subsystem, blue blocks: oxygen supply subsystem, yellow blocks: thermal management subsystem, green blocks: monitoring subsystem)

The window allows the control and visualization of the all important operating parameters of the fuel cell stack. 


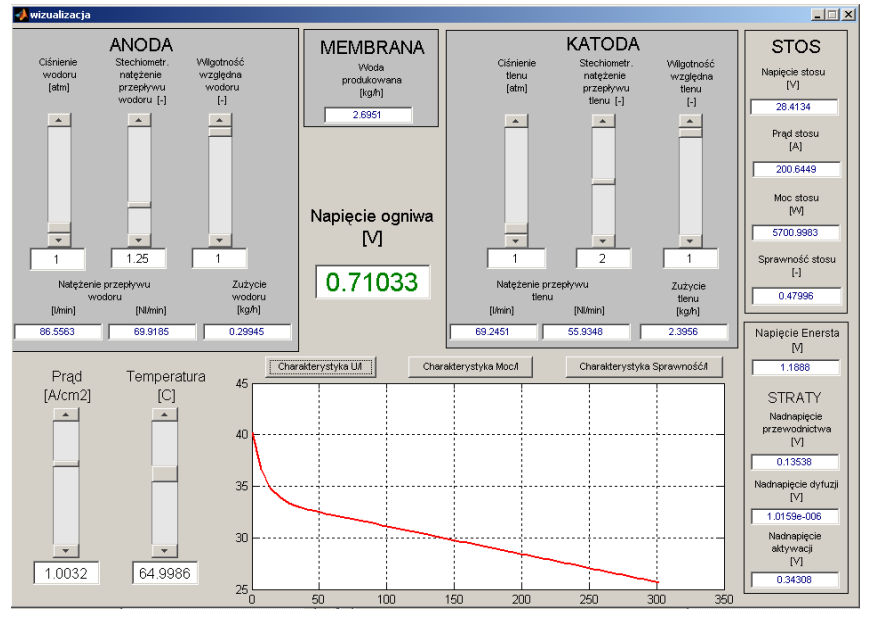

Fig. 3 Visualization of PEM fuel cells parameters in Matlab

The parameters of the model of the fuel cell stack was tuned based on experimental data obtained from the Nedstack company - the manufacturer of $6 \mathrm{~kW}$ stack used in the technology demonstrator (described in more details in the next section). The stack modelling was carried out in cooperation with Stanisław Hożyń [8].

Based on a comparison of characteristics obtained from the model and the real $6 \mathrm{~kW}$ stack [3], it can be concluded that the mathematical model parameters were chosen correctly and implemented simulator properly represents the behavior of the fuel cell stack in steady state. Correctly validated model allowed examine the impact of significant parameters (temperature of the stack, pressure and relative humidity of the reaction gases) on the operation of the fuel cell stack [13][15]. Moreover, it allowed determine the best parameters of its control subsystem [12][14]. At the end, results of numerical research enabled to determine assumptions for building technology demonstrator of emergency power supply system of submarine based on hydrogen fuel cell.

\section{TECHNOLOGY DEMONSTRATOR OF FUEL CELL SYSTEM}

In the next stage, the real technology demonstrator was built. The main purposes of the demonstrator are:

1) the demonstration of possibility of using the PEM fuel cells technology for emergency supply of the submarine, especially at the time of failure,

2) the verification of possibility of using the PEM fuel cells as an alternative source of electric energy on board of a submarine.

In future research the demonstrator can be:

1) an element of the laboratory stand for testing different methods of hydrogen storage,

2) a basis for the training of crews of future submarine with hybrid propulsion consisting of, among others, the fuel cell system.
Finally, the entire system was built in the Laboratory of Electric Drives in Polish Naval Academy (Fig. 4). The demonstrator was named as "Air Independent Electric Supply System" AIESS.

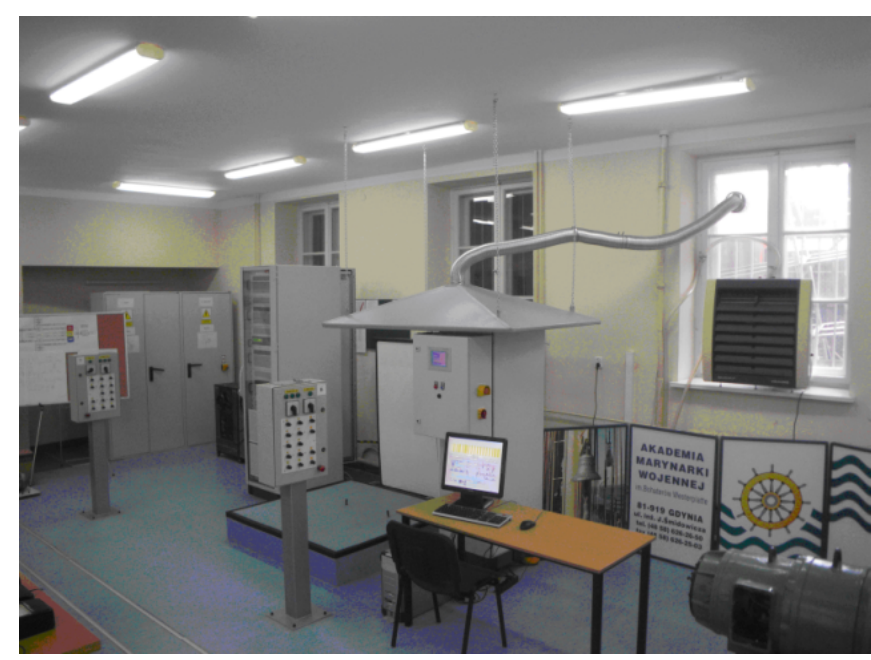

Fig. 4. Technology demonstrator of Air Independent Electric Supply System in Laboratory of Electric Drives

The AIESS consists of:

1) PEM fuel cell system with nominal power $6 \mathrm{~kW}$ based on P8 stack from Nedstack Company, Arnhem, Netherlands,

2) DC/DC converter stabilizing voltage at level $220 \mathrm{~V}$, connected in parallel with supercapacitors,

3) the electric load consisting of: an electric motor, a lighting set and a heating,

4) installations and pressured tanks of oxygen, hydrogen and nitrogen.

The PEM fuel cell system is controlled by S7-300 PLC. The controller is connected with a touch panel and PC through MPI protocol. The touch panel performs Human Machine Interface, whereas $\mathrm{PC}$ visualizes operation and registers parameters of the system. In the Fig. 5, application CVM (Cell Voltage Measure) installed on PC is presented.

The main window of application CVM is divided into the following panels (from top to down):

1) the buttons panel for connecting or disconnecting the PLC application and call the configuration window,

2) the voltage panel showing the voltages on each fuel cell in the form of a bar graph and the minimum, maximum and average value of overall stack voltage,

3) the current state system panel showing the real-time operational status of the system components on its schematic diagram with the display of the main parameters of the AIESS.

The whole registered and visualized parameters are archived in a ${ }^{*}$.text file. It allows to make analyses of the system operation off-line and examine long-lasting processes, e.g. process of membrane deterioration. 


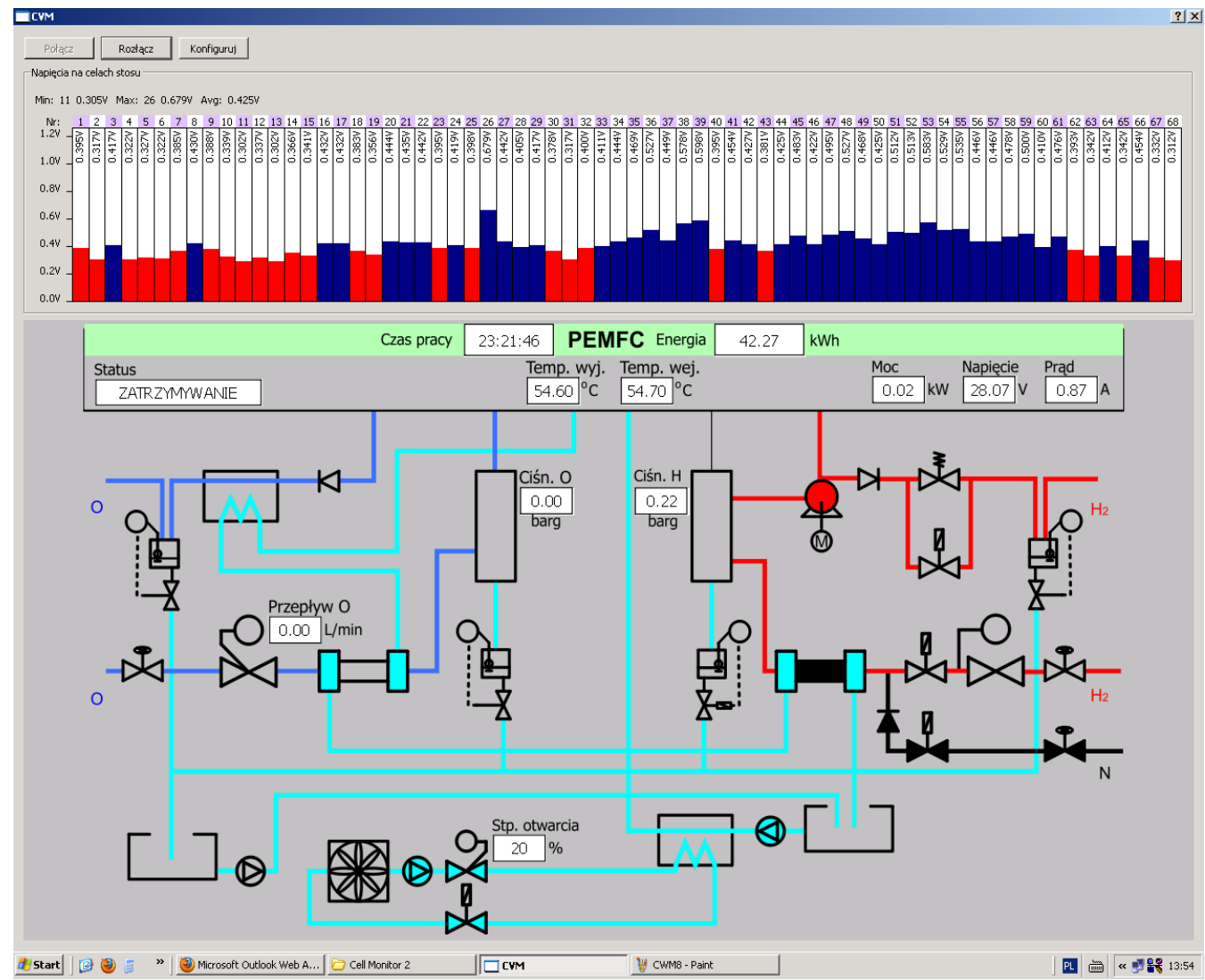

was implemented in Matlab / Simulink environment and then its parameters were tuned to the fuel cell stack from Nedstack company (Arnhem, Netherlands). Details of the research are contained in [3][12][13][14][15].

The second stage of the study was carried out in three phases. In the first phase, the measurement of polarization characteristics of P8 Nedstack PEM fuel cells was carried out. The stack was supplied by clean oxygen. Then, measurement of oxygen excess, appearing at open architecture of oxygen supply subsystem was performed. At the end of the studies, influence of changes of an electrical load on the work of AIESS was examined.

Fig. 5. Application CVM for visualization and registration of parameters of the AIESS

Parameters of the elements of the AIESS included in the reactant gasses supply subsystems, thermal management subsystem, control subsystem, etc. were selected based on the results of simulation studies using the designed mathematical model of the system. Moreover, experiences gathered during collaboration with the companies: Nedstack from The Netherlands and Apisystems Gdańsk and Linde Gas Polska from Poland were used to achieve final version of the AIESS.

It should be underlined that the demonstrator consists of two main parts: the emergency power system creating the proper technology demonstrator and the laboratory stand for its testing. The stand is used for real-time visualization and archivisation of the fuel cell stack operation and the operation of subsystems providing the reaction gases: hydrogen and oxygen with humidification of the reactant gasses and cooling subsystem.

\section{EXPERIMENTAL RESEARCH}

Experimental studies were carried out in two stages:

1) simulation research based on the mathematical model of the fuel cell system,

2) measurement of parameters of fuel cell system called AIESS.

The first stage of the study was carried out using analytical and control-oriented, isothermal and cell-averaged model of the fuel cell stack operating in a steady state. This model

\section{MEASUREMENT OF POLARIZATION CHARACTERISTICS OF THE FUEL CELL STACK P8}

In the first part of the study, measurement of the polarization characteristics of the fuel cell stack P8 was made in the conditions of the stack supply by pure hydrogen and oxygen. Nedstack company - the manufacturer of the stack provided only the polarization characteristics of the stack in the conditions of the stack supplied by pure hydrogen and air (Fig. 6).

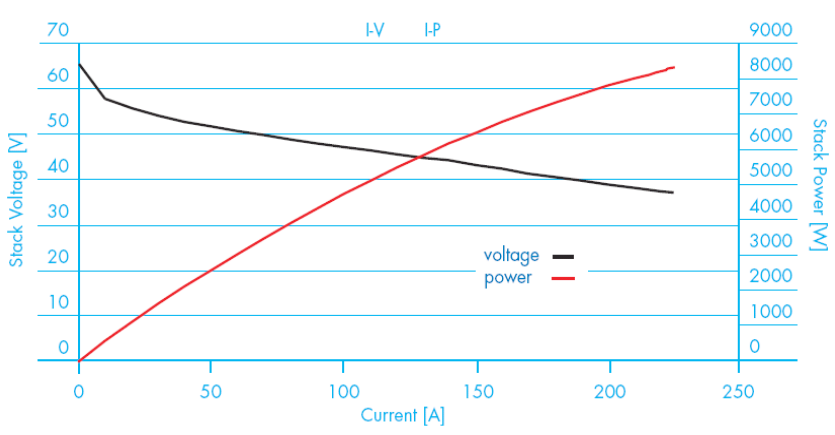

Fig. 6. The polarization characteristics of the fuel cell stack P8 supplied by pure hydrogen and oxygen from the surrounding air (www.nedstack.com)

During the research the stack was supplied by pure hydrogen and oxygen. The course of the measured polarization characteristics of the fuel cell stack P8 (supplied by pure oxygen) is presented in Fig. 7. 

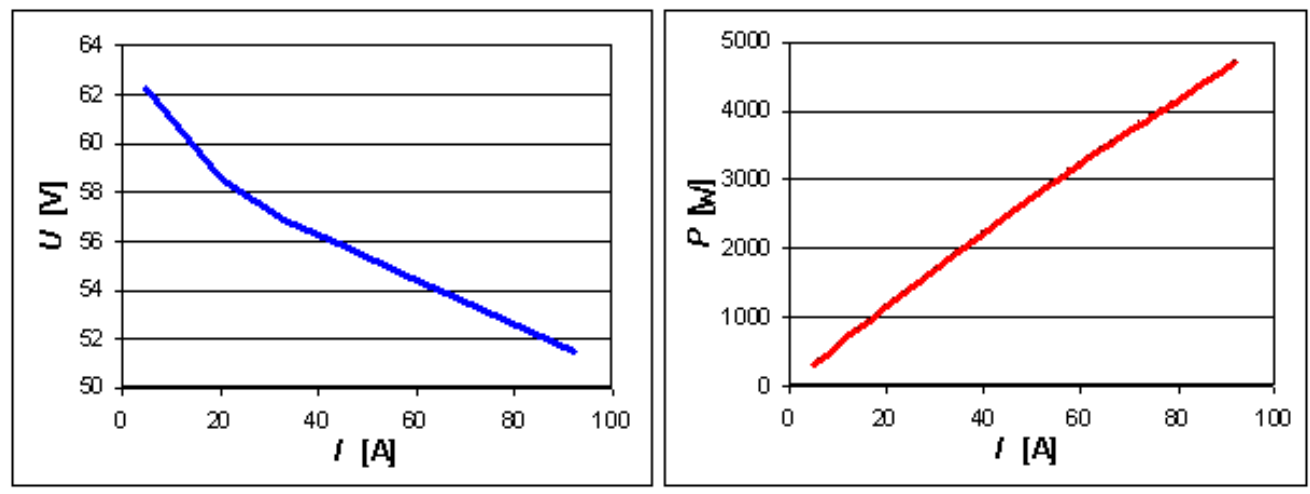

Fig. 7. Polarization characteristics $U(I)$ i $P(I)$ of the fuel xell stack $P 8$ (supplied by pure oxygen)

Comparing the obtained characteristics (Fig. 7 and 8) with the characteristics specified by the manufacturer (Fig. 6), it can be seen a similar course of these characteristics. An important advantage in the case of supplying the stack by pure oxygen compared to the supplying by air is increase of produced power at the output of approx. 10\% (for operating point $100 \mathrm{~A}$ we achieved increase of $7.7 \%$ ). Observed growth of the output power confirmed the numerical results carried out in the previous stage of the study [3][13].

The figure below (Fig. 8) shows the course of the polarization characteristic $P(I)$ in two different temperatures of the fuel cell stack operation: $308,15^{\circ} \mathrm{K}$ and $331,15^{\circ} \mathrm{K}$. As it can be seen (Fig. 8), the higher operating temperature of the fuel cell stack results in a greater efficiency, that is for the same current, the output power is higher. The deviation of the both characteristics increases with the increase of a current load. This is important for the operation of AIESS, that is the system can deliver large currents after reaching operating temperature of the stack $333,15^{\circ} \mathrm{K} \pm 2^{\circ} \mathrm{K}$. It is the temperature range recommended by the manufacturer of the fuel cell - the Nedstack company.

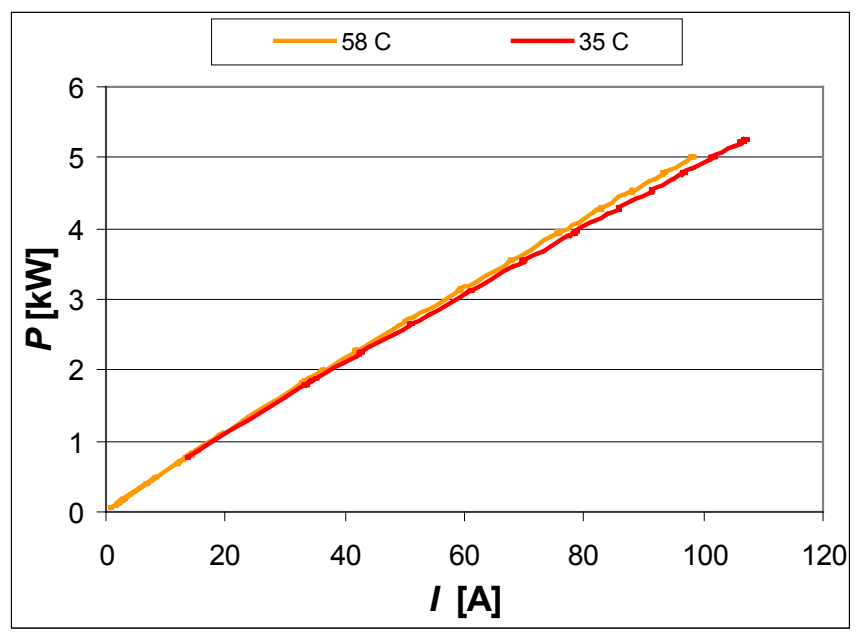

Fig. 8. The polarization characteristics $P(I)$ of the fuel cell stack $P 8$ supplied by pure oxygen for the operating temperature: $308,15^{\circ} \mathrm{K} i 331,15^{\circ} \mathrm{K}$

The temperature has significant importance for the intensity of electro-catalysis process of hydrogen on platinum, that is the higher the temperature, the higher the intensity. Upper limit of the operating temperature range due to the fact that at higher temperatures reduces the relative humidity of the reaction gas, and water in PEM fuel cell is used for the transport of hydrogen protons through the ion-conductive membrane. Therefore, the temperature range recommended by the manufacturer is a kind of a compromise, aimed at finding the best operating conditions of a specific type of PEM fuel cells.

\section{MEASUREMENT OF THE OXYGEN EXCESS AT THE OUTLET OF THE STACK}

As it was mentioned earlier, in this fuel cell system, oxygen supply subsystem was designed and built in an original way, that is the subsystem is without recirculation of oxygen. Such a process of delivering oxygen to the stack requires precise control of the oxygen so that oxygen excess on the output is not too large, that is it could be consumed by the crews.

The measurement of the oxygen excess was preceded by tuning PID settings of oxygen flow implemented in the controller Bronkhorst F-201. As a result of this process, a smooth course of the volumetric flow rate of oxygen at the inlet of the fuel cell was achieved, as shown in Fig. 9. In this figure flow rate is represented in percentages scale, where $100 \%$ corresponds to the flow of $65 \mathrm{Nl} / \mathrm{min}$. Presented in this figure oxygen flow corresponds to a fairly significant step change of a load current: from 6 A to $57 \mathrm{~A}$ and from $57 \mathrm{~A}$ to $92 \mathrm{~A}$, which corresponds to the following changes in output power: from $0.37 \mathrm{~kW}$ to $3.08 \mathrm{~kW}$ and from $3.08 \mathrm{~kW}$ to $4.73 \mathrm{~kW}$ (Fig. 10). The observed initial power $0.37 \mathrm{~kW}$ is due to the fact that the devices, e.g. pumps are powered directly from the fuel cel system, when it started working.

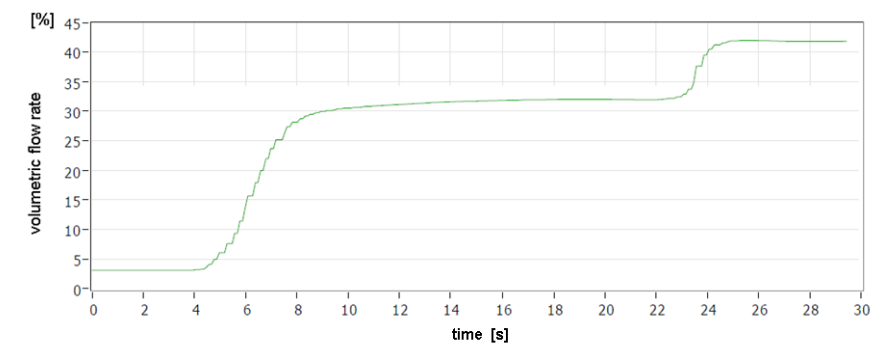

Fig. 9. The course of volumetric flow rate of oxygen at the inlet of the fuel cell stac for a given step change in load current from $6 \mathrm{~A}$ to $57 \mathrm{~A}$ and then to $92 \mathrm{~A}$

As can be seen from Fig. 9, the smooth flow of oxygen corresponds to step changes of current and voltage with a single overshoot equal to $5 \mathrm{~A}$ and $2 \mathrm{~V}$ (Fig. 10). The resulting overvoltage approx. $2 \mathrm{~V}$, corresponds to the voltage drop at the 
single cell equal to $0.05 \mathrm{~V}$ (assuming a uniform distribution on all cells of the fuel stack). This voltage drop is not dangerous for stack operation and potential damage of any cell.

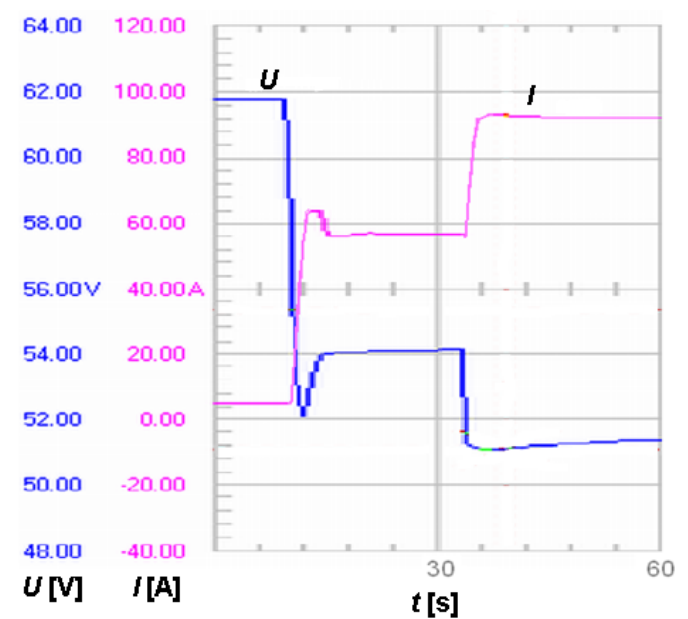

Fig. 10. The course of current and voltage at the output of the fuel cell systemfor a given step change in load current of $6 \mathrm{~A}$ to $57 \mathrm{~A}$ and then to $92 \mathrm{~A}$ (measured by Fluke)

In the Fig. 11, the course of the volumetric flow rate of oxygen excess at the output of the fuel cell stack for the mentioned above step changes of load current is shown. As it can be seen from the graph, the oxygen excess is up to $2.5 \%$, which corresponds to a flow rate equal to $1.62 \mathrm{Nl} / \mathrm{min}$. This oxygen excess is consumed by 5-6 people being in a rest state (it is assumed that the resting human body consumes from 0.25 to $0.35 \mathrm{Nl} / \mathrm{min}$ of pure oxygen). Assuming that the AIESS will be used on board a submarine, where the crew consists of 20 people or more, it can be concluded that the observed excess oxygen does not endanger the health and lives of the crew.

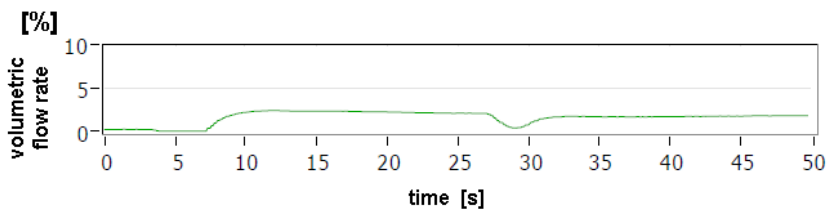

Fig. 11. The course of volumetric flow rate of oxygen excess at the outlet of the fuel cell stack for a given step change of load current from $6 A$ to $57 A$ and then to $92 A$

A higher flow rate than $2.5 \%$ can be observed at the time of reducing the current load. In this case, the following pulse of oxygen flow rate was observed: with the amplitude of up to $7.4 \%(4.8 \mathrm{Nl} / \mathrm{min})$ and the duration approx. $5 \mathrm{sec}$. Registered oxygen flow rates during decrease of the current load also do not pose a threat to the health and life of crew, even if there were continuous.

\section{THE INFLUENCE OF THE LOAD ON THE WORK OF THE FUEL CELL SYSTEM}

In the next phase, the impact of changes of the electrical load (changing continuously, and then jumping) on the AIESS was examined. Many tests of the PEM fuel cell stack were performed, e.g. PEM fuel cells during "heating up" process and then working in the recommended operating temperature range $333,15^{\circ} \mathrm{K} \pm 2^{\circ} \mathrm{K}$, for the given discrete and for continuous load changes, etc. The all results are included in the report on the grant [3]. In the next part of the paper, the time courses of main parameters for the regime with step changes of the load are presented. This regime requires a rapid response system on large changes of an electrical load.

The results of the test for the step increments of an electrical load are presented in Fig. 12 to 16. These step changes simulate the behavior of electrical devices during the state of emergency situation on board of submarine. In the laboratory test, these devices are emergency lighting, electric motor coupled to a generator (ventilation system on board of submarine) and electric heating.

In the Fig. 12, the course of voltage DC/DC converter can be observed. Voltage variations are within the scope $\pm 1 \mathrm{~V}$. This reflects the good work of the DC/DC converter.

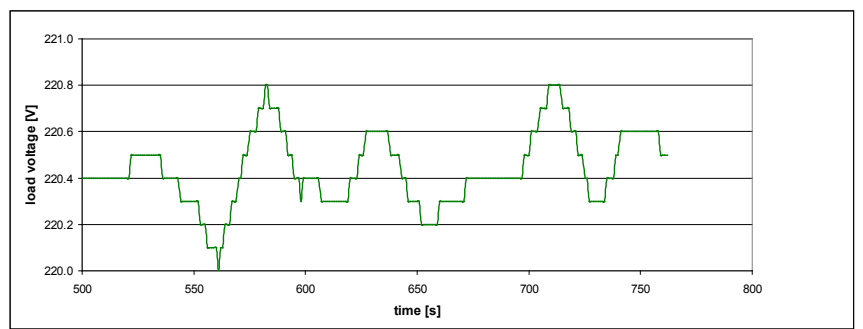

Fig. 12. Stabilization of the load voltage during the test

The changes of the load current described previously correspond to comparable change of current and voltage of the fuel cell (Fig. 13). Only start-up of the electric motor in $516 \mathrm{~s}$ and in $619 \mathrm{~s}$ of the experiment correspond to the pulse increases of the fuel cell current. These pulse increases have short time of duration and result in overvoltage of approx. $10 \mathrm{~V}$. For the fuel cell stack consisting of 68 cells, it gives an average of $0.14 \mathrm{~V}$ voltage drop on a single cell. This poses no threat of damage of the fuel cell stack.

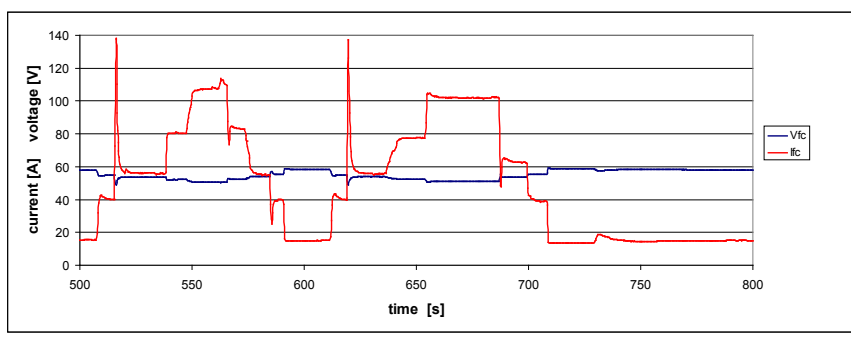

Fig. 13. The course of voltage and current of the fuel cell stack during the test

Described earlier changes of load correspond to small changes of the hydrogen pressure and oxygen (Fig. 14). Small hydrogen pressure changes indicate properly adopted control of hydrogen pressure at the inlet of the stack and the gas pump in the recirculation circuit. Appearing periodically „peaks” of hydrogen pressure waveform are results of the purges of the anode compartment of the stack. The purging is performed cyclically and it is needed for removal of water from anode 
compartment.

The course of the oxygen pressure is closely related to the course of the oxygen flow rate (Fig. 15), which in turn results from the generated power on the load. It was assumed for the technology demonstrator of the fuel cell system that the oxygen flow rate is proportional to the current drawn by the load. The proportionality factor was chosen so that the required power was delivered to the load and the minimum oxygen excess was at the output of the stack.

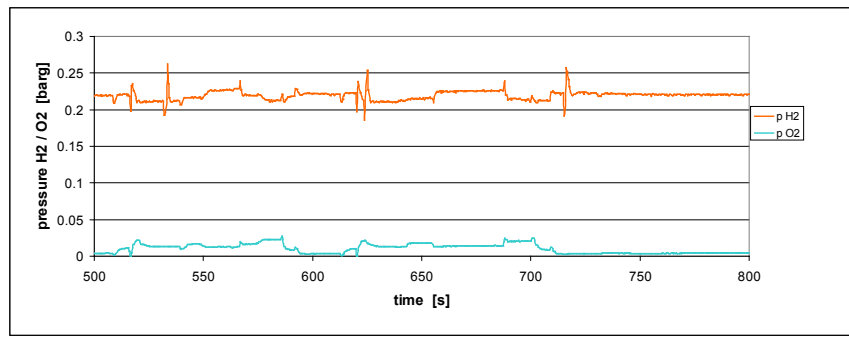

Fig. 14. The course of pressure changes of hydrogen and oxygen during the test

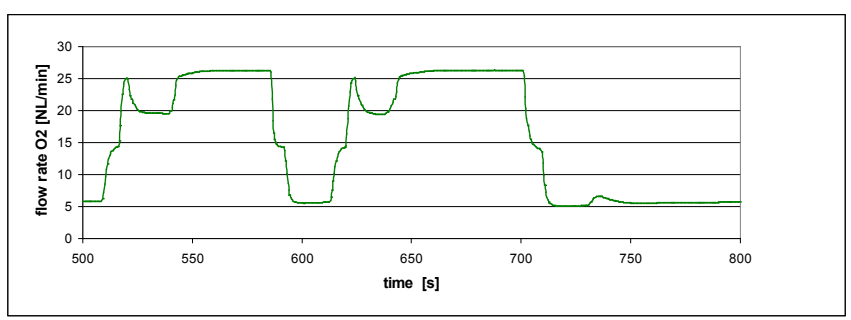

Fig. 15. The course of the oxygen flow rate changes during the test

In the Fig. 16, the changes of temperature at the input and output of the stack are presented. It can be seen that during the increase of the current load, the temperature at the outlet of the fuel cell stack also increases. This is due to the fact that in proportion to the power generated by the fuel cell stack, the losses in the form of heat also increase. Based on the course of the temperature at the stack input, it can also be seen that the heat is effectively transferred into the secondary cooling circuit. Therefore, changes of temperature resulting from the changes of an electrical load is less at the input than at the output of the stack. This demonstrates the proper operation of the cooling system and indicate properly selected heat exchangers and control of the flow of cooling liquid.

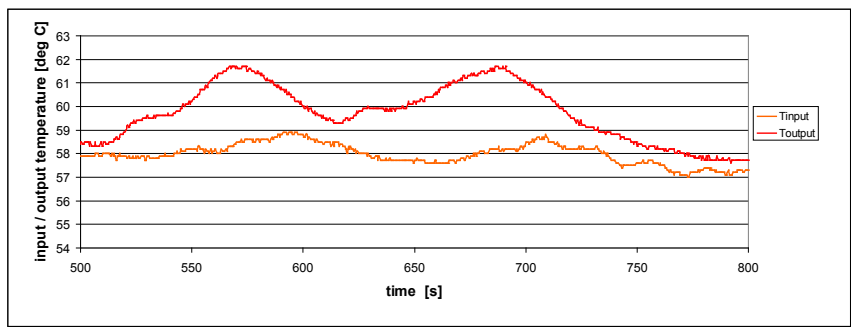

Fig. 16. The course of changes of cooling water temperature at the inlet and at outlet of the fuel cell stack during the test

\section{SUMMARY}

As a final effect of the project, hardware technology demonstrator of emergency power supply system of submarine using a hydrogen fuel cell was built. The parameters of the system meet the requirements regarding the backup power source.

In addition, based on equipment of Laboratory of Electric Drives in Polish Naval Academy the stand for testing the demonstrator was designed and built. Based on the stand many tests were performed that enabled the verification of the simulation model and verification of the design assumptions.

Developed power supply system based on PEM fuel cell adapted to work in the conditions without air correctly responds to changes of a current load and the well stabilizes voltage supplying electric loads, simulating electrical devices during the state of emergency situation on board of submarine.

Performed hydrogen supply subsystem with gas recirculation in a closed-loop enables rapid response of PEM fuel cell stack on changes the electrical load.

The proposed oxygen supply subsystem open due to the reduction in the number of its components, is one of the simplest solutions, and thus potentially the most reliable solution. Registered flow of oxygen excess (appearing at the output of the fuel cell stack) do not pose a threat to life or health of the crew of the submarine. The entire oxygen supply subsystem properly (without threat of the fuel cell stack damage or destruction) responds to the changes of the current load.

The promising result of the project are the hardware facilities and the research team able to carry out further work related to PEM fuel cells technology, especially including the production and storage of hydrogen and optimization of hydrogen cell technology for marine conditions.

\section{ACKNOWLEDGMENT}

For developing the initial concept of using fuel cells for submarines and to initiate research on the fuel cells [3] we thank Professor Zbigniew Korczewski, former Dean of the Faculty of Mechanical and Electrical Engineering in Polish Naval Academy, where the project was implemented.

For professional assistance and cooperation we thank the Director of the Institute of Exploitation of Ship Engine Room Cdr Dr. Tomasz Lus as well as employees of companies Nedstack (Netherlands), Apisystems Gdańsk and Linde Gas Poland (Gdynia branch).

Special thanks to Members of scientific and technical team from the Naval Academy, who worked on the Air-Independent Electrical Supply System.

\section{BIBLIOGRAPHY}

1. Bujło P.: Polymeric super ionic membranes for fuel cell PEMFC, in Polish, PhD thesis, Wrocław University of Technology, Wrocław 2006. 
2. Gasser F.: An analytical, control-oriented state space model for a PEM fuel cell system, PhD thesis, Ecole Polytechnique Federale de Lausanne, Lausanne 2006.

3. Grzeczka G., Szymak P.: Grant Report on Air Independent Electric Supply System based on PEM Fuel Cell, in Polish, Main Library Archive, Polish Naval Academy, Gdynia, Poland, 2010.

4. Hammerschmidt A. E.: Fuel Cell Propulsion of Submarines, Advanced Naval Propulsion Symposium 2006, October 30 - 31, 2006, Arlington, VA, USA.

5. Hasvold Ø., Johansen K. H., and Vestgaard K.: The alkaline aluminum hydrogen peroxide semi-fuel cell for the HUGIN 3000 autonomous underwater vehicle, Proceedings of the 2002 Workshop on Autonomous Underwater Vehicles, San Antonio, 2002, USA, pp. 89-94.

6. Hasvold Ø., Lian T., Haakaas E., Størkersen N., Perelman O., and Cordier S.: CLIPPER: A long-range, autonomous underwater vehicle using magnesium fuel and oxygen from the sea, Journal of Power Sources, Vol. 136, 2004, pp. 232-239.

7. Hasvold $\varnothing$. and Størkersen N.: Electrochemical power sources for unmanned underwater vehicles used in deep sea survey operations, Journal of Power Sources, Vol. 96, 2001, pp. 252-258.

8. Hożyń S., Żak B.: Fuzzy Control of Reactant Supply System in PEM Fuel Cell, Trans Tech Publications, Solid State Phenomena, 2012, Vol. 180, pp. 11-19.

9. Korczewski Z., Szac P.: Technical Conditions of Using Fuel Cells for Reserve Electric Supply of Kobben Submarine, in Polish, Scientific Journal SYMSO 2006, pp. 65 - 72.

10. Nguyen P.T.: A Three-Dimensional Computational Model of PEM Fuel Cell with Serpentine Gas Channels, University of Western Ontario, 2001.

11. Pukrushpan J., Stefanopoulou A., Peng H.: Control of Fuel Cell Power Systems, Advances in Industrial Control, Springer, London 2004.

12. Szymak P., Grzeczka G.: Control of Oxygen Flow in Air Independent PEM Fuel Cell System, Conference Proceedings of $5^{\text {th }}$ Hydrogen \& Energy Symposium, Stoos 2011.

13. Szymak P.: Mathematical model of PEM fuel cell stack supplied with clean oxygen and hydrogen, in Polish, Institute of Logistics and Storage, Logistyka, No 3, 2009, pp. 78-85.

14. Szymak P.: Control of Thermal Management Subsystem of PEM Fuel Cell Stack, HARD Publishing Company, Polish Journal of Environmental Studies, Vol.18, No.4B, 2009, pp. 187-190

15. Szymak P.: Influence of working temperature of PEM fuel cell on its power and efficiency, Institute of Logistics and Storage, Logistyka, No 6, 2009, pp. 254-261.

16. Yamamoto I., Aoki T., Tsukioka S., Yoshida H., Hyakudome T., Sawa T., Ishibashi S., Yokoyama K., Maeda T., et al.: Fuel Cell System of AUV 'Urashima', Conference Proceedings of IEEE Oceans/Techno-ocean, 2004.
17. Żółtowski B., Żółtowski M.: A hydrogenic electrolyzer for fuels, Polish Maritime Research, No. 4(84) Vol 21, 2014, pp.79-89.

\section{CONTACT WITH THE AUTHOR}

Grzegorz Grzeczka

e-mail: g.grzeczka@amw.gdynia.pl

Polish Naval Academy

Śmidowicza Street 69

81-127 Gdynia

Poland 